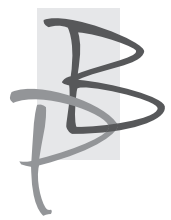

Halina Turkiewicz*

Akademia Edukacji Uniwersytetu Witolda Wielkiego (Wilno)

https://orcid.org/0000-0002-4368-7063

\title{
Motywy łotewskie w poezji Kazimiery Iłłakowiczówny
}

Streszczenie: Artykuł omawia zrąb twórczości Kazimiery lłłakowiczówny (1888-1983), który powstał podczas pobytu poetki na Łotwie na przełomie XIX-XX wieku. Poszczególne wiersze, zwłaszcza składające się na tomik Popiół i perły, przywołują realia i szczegóły pejzażowe konkretnych miejscowości ziemi łotewskiej, z ciepłem i życzliwością odmalowują bliżej poznanych bądź sporadycznie widywanych ludzi, ich mentalność i liczne walory wewnętrzne. Poetka tworzy wielobarwną, wielokulturową mozaikę, wpisując się do nurtu poezji regionalnej.

Słowa-klucze: motywy łotewskie, realia pejzażowe, portrety postaci, wielokulturowość, regionalizm.

\section{Latvian motifs in the poetry of Kazimiera Iłłakowiczówna}

Summary: The present article explores the pieces of poetry of Kazimiera Iłłakowiczówna (1888-1983) that were inspired by her stay in Latvia in her childhood at the turn of the 19th-20th centuries. Her individual

* Halina Turkiewicz - dr, docent w Akademii Edukacji Uniwersytetu Witolda Wielkiego (Wilno), historyk literatury polskiej, nauczyciel akademicki; autorka licznych artykułów naukowych dotyczących literatury polskiej XX wieku, w tym też literatury polskiej na Litwie: Litewsko-romantyczne motywy w twórczości Kazimiery Itłakowiczówny (1996), Helena Romer-Ochenkowska jako publicystka , Kuriera Wileńskiego” w latach dwudziestych XX wieku (2000). 
poems, especially those making up the collection Popiół i perły, depict the features and reality of the landscape of particular places in Latvia, evoke feelings of warmth and kindness towards the people she had met as well as reflect their mentality and virtues. Kazimiera Iłakowiczówna creates a multicoloured, multicultural mosaic, which makes a part of regional poetry.

Key words: Latvian motifs, features of the landscape, portraits of characters, multiculturalism, regionalism.

Kazimiera Iłłakowiczówna (1888-1983) nie należy dzisiaj do pisarek często przywoływanych, chociaż zostawiła po sobie zasługujący na uwagę dorobek poetycki. Historia literatury polskiej wyznacza jej dość skromne miejsce, najczęściej wśród tak zwanych satelitów „Skamandra”, gdyż poetka nie odrzuca tradycji, nie gardzi lubowaniem się prostotą, sięga po różnorodne motywy i formy ekspresji twórczej. Wpisuje się ona także w nurt poezji religijnej, bywa zestawiana z poetami pokroju Leopolda Staffa, Jerzego Lieberta, Wojciecha Bąka. Ten zrąb twórczości autorki doczekał się nawet opracowania monograficznego. Mam na myśli książkę Mirosławy Ołdakowskiej-Kuflowej Chrześcijańskie widzenie świata w poezji Kazimiery Iłłakowiczówny ${ }^{1}$.

Brakuje jednakże całościowego spojrzenia na poezję autorki Słowika litewskiego, a więc takiego, które musiałoby uwzględnić w równym stopniu uniwersalne oraz regionalne aspekty twórczości, jej związek z konkretnymi przestrzeniami na Litwie i Łotwie, z którymi było związane najwcześniejsze dzieciństwo (urodziła się w Wilnie) oraz bardziej świadome lata dorastania (Baltyn i inne miejscowości na Łotwie).

Miejsca urodzenia się nie wybiera. Przyszła poetka jako osoba wcześnie osierocona przez oboje rodziców nie mogła samodzielnie wybierać miejscowości stałego pobytu. Przygarnięta początkowo przez wuja, Jakuba Iłłakowi-

1 M. Ołdakowska-Kuflowa, Chrześcijańskie widzenie świata w poezji Kazimiery Iłtakowiczówny, Lublin 1993. 
cza, nie znajdująca jednak należytej opieki w jego rodzinie, zwróciła na siebie uwagę wielkiej filantropki, Zofii z Zyberk-Platerów Buynowej, która w swoich majątkach na Łotwie utrzymywała mnóstwo wychowanek, zapewniając im nie tylko odpowiednie warunki materialne, lecz także wykształcenie i start życiowy. W taki sposób mała Kazimiera, przypuszczalnie jako siedmioletnie dziecko, znalazła się w Baltynie, trafiając bezpośrednio pod oko opiekunki. Pobyt ten dawał możliwość odwiedzania również położonych w okolicy majątków Zofii Buynowej, która stała się dla niej matką. Gdyby nie ten właśnie epizod w życiorysie, nie byłoby zapewne śladów Łotwy i „łotewskości” w poezji Iłłakowiczówny.

Motywy łotewskie, podobnie zresztą jak litewskie, nie od razu pojawią się w twórczości naszej bohaterki. Zanim do tego dojdzie, wyda ona debiutanckie, wynikające z uzależnienia od maniery romantycznej, poszukujące własnej ścieżki artystycznej Ikarowe loty (1911). Następnie pojawi się zainteresowanie poezją patriotyczną, współbrzmiącą z oczekiwaniami całego narodu tęskniącego do wolnej Polski, współczującą twardemu losowi rodaków, czego świadectwem są Wici (1914), Trzy struny (1917) oraz Kolędy polskiej biedy (1917).

Zbiorek poetycki Śmierć Feniksa (1922) i następujące po nim dają właśnie podstawę do znajdowania wielu zbieżności z poezją skamandrycką. Tak oto wypracowuje się powoli osobowość twórcza, która będzie stale odtąd cechowała dzieła autorki Połowu. Matylda Wełna pisała o wierszach poetki:

Zdumiewa [...] prawda szczegółu, bystre, zachłanne oko, które wszystko widzi, nawet rzeczy drobne, mało ważne, przez innych pomijane, niedostrzegane. Od dzieciństwa zżyta z przyrodą, umie na nią patrzeć, kontempluje wszystkie jej przeobrażenia, nasyca się jej pięknem. Wiersze Hłakowiczówny, gdy się im dobrze przyjrzeć, to właściwie drobiazgowe opisy, jakich nie powstydziłby się rasowy prozaik, tyle że magią talentu przemienione w urzekające świeżością spojrzenie liryka. Zadziwia dokładność relacji, jej kompletność, plastyczność, aż po najdrobniejsze fakty. I to w dużej mierze decyduje o wyjątkowości tych wierszy, o ich oryginalności $[\ldots]^{2}$.

2 M. Wełna, Wierność życiu, [w:] K. Iłłakowiczówna, Poezje, Lublin 1989, s. 5. 
Nieprzypadkowo przywołaliśmy dłuższy cytat ze wstępu do Poezji Iłłakowiczówny. Wyeksponowane cechy poetyki autorki Płaczacego ptaka uwydatniły się jeszcze bardziej w wierszach, w których wychowana na ziemiach kresowych twórczyni wraca do wspomnień litewsko-wileńskich czy łotewskich. Nabierają one aktualności zwłaszcza w tomikach wydanych w latach trzydziestych XX wieku, a są to Popiót i perty (1930), Ballady bohaterskie (1934) oraz Stowik litewski (1936). Jako że przywoływane przez poetkę obrazy i rekwizyty litewsko-wileńskie znalazły nieco szersze ujęcie w moim wcześniejszym artykule Motywy battyckie w poezji Kazimiery Itłakowiczów$n y^{3}$, ograniczmy się tym razem do analizy realiów łotewskich, w które obfituje zwłaszcza zbiorek poetycki Popiół i perły. Znajdujemy tu nawet osobny cykl wierszy Dom nasz, będący lirycznym hołdem niegdysiejszej małej ojczyźnie, przestrzeni dzieciństwa i młodości.

Kreując krajobraz litewski czy łotewski, wymieniając jego wyznaczniki, poetka dość często, nie tylko w tytule przywoływanego cyklu wierszy, stosuje zaimki dzierżawcze typu „u nas”, „,nasz”, „nasze”, „moje”. Na przykład:

[...] U nas wyjdziesz na drogę o świcie,

a już mały ptak zbudził się w życie, już jaskółka pod strzechą szczebiota; koń, w kosmate spętany postronki, podniósł głowę i patrzy we wrota; skrzypnął żuraw, zachlupała woda... A na niebie pogoda, pogoda, A pod niebem skowronki, skowronki! ${ }^{4}[\ldots]$

Identyfikowanie się z naturą, z pejzażem, z wpisanymi weń ludźmi nabiera wyrazu właśnie w cyklu Dom nasz, który wskrzesza łotewskie doświadczenia poetki, wspominane po latach bardzo ciepło, serdecznie. Na marginesie lektury pamiętników znanego etnografa i podróżnika poetka odnotowała:

3 H. Turkiewicz, Motywy baltyckie w poezji Kazimiery Itłakowiczówny, [w:] Meninis tekstas: Suvokimas. Analize. Interpretacija, nr 6, Vilnius 2008, s. 215-222.

4 K. Iłłakowiczówna, Poezje, Lublin 1989, s. 52. 
Jakże dziwne, jak szczególne wrażenie robią na mnie urocze pamiętniki Bolesława Limanowskiego... Bo okolica jego lat dziecinnych to moja okolica. Więc nawet Stanisławowo... Mój Boże, tyle lat, a jeszcze - krwawi! I Podgórze, i Sztarnberg, i Druja, i Krasław, i Dorotpol, a wreszcie Indryca, moja parafia, dokąd ze Stanisławowa chodziło się nawet na piechotę. Malutkie to było i nie pamiętałam wcale, że drewniane, nad ołtarzem widniał jakiś stareńki obraz nie obraz, fresk nie fresk - albo to człowiek w dzieciństwie rozróżnia! - dość że pamiętam drzewo o płaskiej koronie, a pod nim Adama i Ewę.

lleż to razy patrząc na pomnik Szopena dłuta Szymanowskiego z tą jego wierzbą, grzebałam i grzebałam w pamięci... Coś mi on przypominał... Aż teraz, kiedy z grubej księgi tych serdecznych, ludzkich pamiętników wyjrzała ku mnie fasada indryckiego kościółka, już wiem: wierzba z pomnika przypominała mi drzewo nad ołtarzem w Indrycy 5 .

Cykl wierszy Dom nasz uwydatnia zżycie się poetki z ludźmi i pejzażem dzieciństwa w majątkach niestrudzonej Zofii Buynowej. Jest on wyrazem sentymentu wobec bliskiej niegdyś przestrzeni. Iłłakowiczówna kieruje swoje strofy jakby do konkretnego odbiorcy, oswojonego z podobnym pejzażem, wrośniętego weń od samego dzieciństwa, ponadto podkreśla, że pisze te wiersze Nie dla obcych:

Ten las, ten ogród, ten dom,
te porosłe cząbrem manowce
to nie są wiersze dla was,
to nie są wiersze dla obcych! [...]

Studnie i bagna, i jezior toń nagła, Iniane dzieweczki i w płótniankach chłopcy...

Lecz cokolwiek się tworzy - tytuł trzeba położyć:

"Dla swoich - nie dla obcych" ${ }^{\text {. }}$

5 K. Iłłakowiczówna, Trazymeński zając, Kraków 1968, s. 12.

6 Tamże, s. 153-154. 
Zestawiając ze sobą poświęcone Litwie i Łotwie wiersze, można odnieść wrażenie, że krajobraz łotewski charakteryzowany jest bardziej konkretnie i szczegółowo niż litewski. Chodzi o to, że na Łotwie przebiegały bardziej świadome dzieciństwo i młodość poetki, większość kreowanych obrazów ma u podstawy jakieś fakty $\mathrm{z}$ autopsji. Niejeden z zamieszczonych $\mathrm{w}$ cyklu wierszy przywołuje nazwy topograficzne: Stanisławowo, Baltyn, Krasław, Indryca, Iłłukszta, Liwczany i inne. Niektórym miejscowościom i związanym z nim obiektom czy przeżyciom poświęca poetka osobne wiersze: Liksnieńska kniejka, Folwark na Sztarnbergu, Dwór w Dorotpolu, Cmentarz w Jurahowie $\mathrm{i}$ inne.

Ostatni wpisuje się w szerszy kontekst, jeżeli tak można powiedzieć, wierszy „cmentarnych” Kazimiery Iłłakowiczówny. Cmentarze, groby, mogiły, opisywane bezpośrednio albo wpisane w tło takiego czy innego pejzażu, to częsty motyw jej poezji:

Po stromym urwisku czeremcha się wspina;

śpią w brzozowej kniejce dziedzice Baltyna.

Płynie łąką bystry ruczaj,

młyn daleko stuka, huczy,

z wzgórz okolicznych pachnie las sosnowy

i dymy lecą od Baltyna i Jurahowa?

Jako osoba niemająca możliwości odwiedzania pozostawionych na Litwie grobów rodzicielskich, chętnie odwiedzała i w razie potrzeby także sprzątała obce miejsca pochówku, czego świadectwo znajdujemy w tym wierszu:

Przychodzimy o wczesnym ranku, na przełaj przeciąwszy drogę.

„„...Trzeba pomóc biednym umarłym, a oni nas też kiedyś wspomogą...”

Mamy łopaty i grabki, ciężko pracujemy schylone.

"Trzeba oczyścić mogiłki śpiącym kurlandzkim baronom."

Równamy ślady racic, podźwigamy upadłe krzyże...

„I oni nad nami się schylą, kiedy śmierć się do nas przybliży!"8

7 Tamże, s. 156.

8 Tamże. 
Są tu także przestrzenie naznaczone przez historię, chociaż nieraz bezimienne, jak na przykład Puste miejsce, ,rozlokowane za Murowanką, niedaleko Krasławia [...] / Tam powstańca Moskale zabili”.

I są przestrzenie ewokujące pamięć o najbliższych, zwłaszcza o przybranej matce, Zofii Buynowej, wspominanej między innymi w wierszu Mogiła.

W opisie krajobrazu łotewskiego nie brakuje motywów akwatycznych, związanych z poetyckim opisem konkretnej miejscowości. Mam na myśli takie wiersze, jak Wabolskie Jezioro czy Moje rzeki:

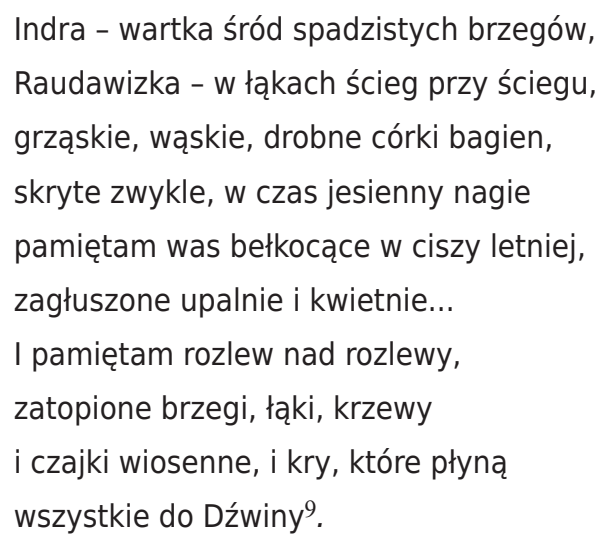

Przywoływany krajobraz ożywia w poszczególnych wierszach bogata galeria postaci, kreowanych przez poetkę w cyklu Dom nasz. Z biegiem lat kierująca się coraz bardziej ewangelicznymi wartościami Kazimiera Iłłakowiczówna z miłością i czułością wydobywa z pamięci wielu domowników, mieszkańców tego czy innego dworu, w którym przyszło jej się zatrzymać. O ciepłym stosunku emocjonalnym do prezentowanych osób świadczy już sam fakt zwracania się do nich po imieniu: Barbara, Donat, Józia, Magdalena, Wasyl i inni. Szczególnymi względami w poezji Iłłakowiczówny cieszą się służące, gosposie, nazywane także po imieniu: Agatka, Hania, Marianna, Marysia i inne. Tej kategorii domowników poświęciła zresztą osobny cykl wierszy, który tak się właśnie nazywa: Stużące.

Wyjście z domu czy poza teren przydomowy stwarzało możliwość obserwowania ludzi, poznawania innych, niż przyjęte w najbliższym otoczeniu, 
obyczajów. Na utrwalenie w wierszu zasługują i bliżsi, i dalsi, i zupełnie czasem nieznani, dziwni ludzie, jak „siwowłosa” w utworze $Z$ psami. Wiersze im poświęcone genologicznie przypominają literacki obrazek. Są nieraz przywołaniem konkretnej sytuacji zaczerpniętej z autopsji. Bo jakże inaczej interpretować takie teksty, jak, powiedzmy, Dwór w Dorotpolu:

\author{
Nad jeziorem - aleja lipowa: \\ tam mieszkała pani Piotrowiczowa. \\ Dwór miała rozłożysty, sad wielki i stromy, \\ kiedykolwiek się przyszło, zawsze była w domu; \\ nastawiała konfitur na białej serwecie \\ i mówiła: „To dla was, dzieci. Jedzcie... jedzcie!”10
}

Przebywająca na ziemiach pogranicza Iłłakowiczówna zderzyła się z charakterystycznym dla takich regionów tyglem narodowościowym, językowym, wyznaniowym, kulturowym, obyczajowym. Nie dziwi zatem fakt, że w wierszach-obrazkach, przywołujących sytuacje, których była świadkiem, poetka operuje takimi określeniami, jak na przykład Starowiery czy Kacapi. Ostatni, bez względu na obraźliwy na pozór tytuł, są scharakteryzowani nie bez pewnej dozy wdzięku, humoru, rubaszności i przychylności:

\footnotetext{
Kacapi jedzą powoli pod jabłonią barszcz okazały, kapustę pełną woni: hoże im służą dziewki, wielkonogie baby. Czaj piją, jedzą znów, aż człowiekowi słabo, a potem, rozpostarłszy na ziemi kapoty, kładą się rozczesując brody jasnozłote, żegnają ziewające paszcze jeszcze pełne chleba i jasnymi oczyma w jasne patrzą niebo ${ }^{11}$.
}

10 Tamże, s. 157.

11 Tamże, s. 161. 
Przywołany wiersz jest przykładem umiłowania przez Iłłakiewiczównę konkretu i szczegółu, pokazuje też jej umiejętność łączenia treści wyższych i niższych, stylizacji na język regionalny („,czaj”, „kapoty”).

Życzliwie, ciepło, a nawet $\mathrm{z}$ wielką dozą powagi, dostojeństwa potraktowani są Żydzi, o czym świadczy wiersz Dzierżawca sadu, w którym tytułowa postać najzwyklejszego człowieka urasta do rangi bohatera biblijnego:

\author{
W sadzie pod jabłonią oliwną \\ stoi stary, stary Żyd z brodą niby Noe [...] \\ albo, nieco dalej, o tym samym bohaterze: \\ [...] spojrzał uroczyście jak Abraham, [...] \\ [...] krokiem arcykapłana ruszył w moją stronę ${ }^{12}$.
}

W wierszu Dawidek i jaśmin występuje ,pobożny, młody, poważny Żyd”, który jest niezwykle wrażliwy na piękno przyrody.

Niektóre teksty kreują zbiorowy obraz ludzi „tutejszych” i „tamtejszych”, w zależności od przyjętej perspektywy. Informują o tym nieraz już same tytuły: Nasze dziewczęta, Tamtejsze dzieci, Tamtejsi.

$\mathrm{W}$ pierwszym z wymienionych pozytywnie oceniono i przedstawiono:

Senne, łagodne łotewskie dziewczęta:

wszystkie suknie krochmalone, żadna nie wymięta,

chustki jedwabne, białe...

Łąki, co przejść nie dały,

kurz, co się stopom sprzeciwiał,

złość cierni i igliwia,

kundle biegnące $z$ ujadaniem w ślad

przezwyciężone. Oto już wstępują w księży sad

i orszakiem dostojnym, przy ramieniu ramię, idą pod kwitnącymi słodko czereśniami ${ }^{13}$.

12 Tamże.

13 Tamże, s. 163-164. 
Wiersz Tamtejsze dzieci to niemal fotografia, migawka utrwalająca lekcje dawane niegdyś przez poetkę miejscowym i okolicznym dzieciom:

\author{
Czyście dzisiaj szczęśliwsze, \\ czy lepszy dzień wam świta, \\ małe tamtejsze dzieci, \\ które uczyłam czytać? \\ Przychodziły z Liwczan, \\ przybywały z Kokiń, \\ w oczach miały siwych, modrych \\ spokój głęboki. [...]
}

Wiersz jest niezwykle konkretny, plastyczny, przedstawione w nim scenki łatwe są do wyobrażenia. Opisano realia nie tylko upiększające scenerię (,siwy ze starości bez patrzał / na kajety od literek coraz pstrokatsze”), ale także uciążliwości, niedogodności, jakie towarzyszyły żmudnej pracy (,Zlatywały się roje much, / coraz bardziej słabł w nas wszystkich duch"). Przypomina to w jakimś stopniu realia i poetykę stosowane przez Czesława Miłosza w poemacie Gdzie wschodzi stońce i kędy zapada, w którym artysta odtwarza, jak wiadomo, swoje mniej i bardziej fascynujące wtajemniczenia na Laudzie.

Jako że wszystko podlega prawu przemijania, wydłużające się lekcje także miały swój kres:

\author{
Schodził wieczór matczyny, głęboki, \\ kurz obfity nad drogami rósł \\ i z wolna ku domowi, pośród młodych brzóz, \\ odchodziły dzieci do Ruchmana, do Liwczan, do Kokińn ${ }^{14}$.
}

I wreszcie swego rodzaju podsumowaniem, uogólnieniem obrazu zapamiętanych ludzi regionu jest wiersz Tamtejsi, który można traktować jako złożenie najwyższego hołdu dla poznanych na Litwie i Łotwie ludzi:

14 Tamże, s. 163. 
Jacyż to nasi tamtejsi?

Bledsi, chudsi, Iżejsi, mniejsi.

Piechotą na jarmark idą,

by ich podwiózł - proszą Żyda;

służą starowierom ich parobcy,

nie strzyżeni, niepiśmienni... Ciche owce!

Tyfus ich dziesiątkuje coraz i cholera,

tacy byli w mym dzieciństwie... Jacyż oni teraz?

Dzieci ich patrzą jak blade kwiatki Inu,

psy ich zawsze wyją, skomlą - nie znają snu...

W kościele łanem się chylą zbitym przez grad,

ten najszczęśliwszy z nich, co krzyżem padł;

hostia nad nim wzniesiona jaśnieje niezwykle...

O święci, nieznani święci Łotwy i Litwy! 15

Ten wiersz zwrócił także uwagę Mirosławy Ołdakowskiej-Kuflowej, która omawia go w kontekście utworów Iłłakowiczówny o „świętych i świątobliwych”, zwracając uwagę na to, że postacie „maluczkich” są częstym zjawiskiem jej poezji:

Iłłakowiczówna w swej poezji wiele miejsca poświęca ubogim, prostym ludziom, służącym, dzieciom biedaków, a nawet tym, którzy należą do marginesu społecznego. Patrzy na znajdujących się na najniższych szczeblach drabiny społecznej przez pryzmat nauki ewangelicznej ${ }^{16}$.

W taki oto sposób przestrzeń regionalna nabiera cech sakralnych, jest miejscem niepozbawionym co prawda skazy, ale bogatym w takie wartości, jak szczerość, prostota, przywiązanie do sfer duchowych człowieka.

Tak samo ciepło i serdecznie malowana jest w wierszach Iłłakowiczówny przyroda. Bywa ona traktowana jako równorzędny partner człowieka, co zostało uwydatnione w Inwokacji, w której monolog liryczny skierowany jest do drzew, w tym konkretnym wypadku - do brzóz:

15 Tamże, s. 162.

16 M. Ołdakowska-Kuflowa, dz. cyt., s. 92. 
Proszę was, brzozy znajome od Dźwińska do Mołodeczna, jeśli was kiedy odwiedzę, niech mi droga będzie bezpieczna. Poczwórnym stoicie szeregiem, szumicie pochwórnym rzędem... ...Dajcie mi cień miłosierny, gdy przejeżdżać będę tamtędy. [...] $]^{17}$

Poetka jest nadzwyczaj wrażliwa na powaby przyrody ojczystej. W jej wierszach „rosną” nie abstrakcyjne drzewa, ale drzewa przywoływane najchętniej ze wspomnień dzieciństwa i młodości, nazywane konkretnie, „po imieniu”, a więc graby, buki, świerki, sosny, topole, dęby, klony, lipy i oczywiście uświęcone przez tradycję Mickiewiczowską brzozy.

Kreując przestrzeń regionalną w podobny sposób, wprowadza też nazwy kwiatów, ptaków i owadów. Kwiaty upiększające poezję Iłłakowiczówny jawią się zatem jako storczyki, bławatki, jaśmin, bez, malwy, róże, bratki, stokrotki i inne.

Ptaki zapamiętane z regionalnej czasoprzestrzeni dzieciństwa to także nie ptaki w ogóle, lecz wrony, kawki, sójki, wróble, czajki, jaskółki, skowronki, słowiki i tak dalej.

Niebezimiennie przywoływane są także owady: komary, muchy, koniki polne, świerszcze, pszczoły.

Realia pejzażowe kreowane są czasem ambiwalentnie. W pewnych wypadkach mamy do czynienia wręcz z sakralizacją przestrzeni, w innych ojczysty pejzaż cechują też „kurz”, „miedze ubożuchne”, „kałuże”, „tuman”, „bajora”, „pyły”, „zgniła pogoda”. Niezależnie jednak od tego, w jakie decorum ubrany jest pejzaż, jest on zazwyczaj bliski podmiotowi.

Można stwierdzić, że występujące w poezji Iłłakowiczówny motywy łotewskie (jak też litewskie) zabarwiają jej twórczość regionalnie, wpisując autorkę w nurt literatury „małych ojczyzn” czy literatury pogranicza.

W poezji twórczyni Popiołu i pereł uwypukliły się tak charakterystyczne cechy literatury regionalnej, jak wyeksponowany koloryt lokalny, kreowany za pośrednictwem wprowadzania nazw topograficznych, artystycznego odmalowywania osobliwości krajobrazowych, mentalności, obyczajów związanych z regionem ludzi, reprezentujących wielonarodowość, wielowyznaniowość,

17 K. Iłłakowiczówna, dz. cyt., s. 171. 
wielokulturowość, wielojęzyczność ${ }^{18}$. Większość utworów cechuje pozytywna tonacja emocjonalna, czasem wręcz sakralizujący stosunek do przedmiotu opisu, gdy tym obiektem jest kraj lat dziecinnych.

Cykl wierszy Słowik litewski, który nadał tytuł tomikowi z 1936 roku, jest poświęcony pierwszej „małej ojczyźnie”, jaką stanowiła dla poetki Litwa, zwłaszcza rodzinne Wilno. Jednakże i w tym tomiku zdarzają się z rzadka uogólnienia, syntetyzujące wspomnienia kresowe, czego wymownym przykładem jest chociażby wiersz Inna jesień:

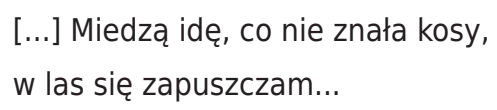

[...] Miedzą idę, co nie znała kosy,

w las się zapuszczam...

Cóż, gdy całkiem innym wabi głosem litewska puszcza.

A czy bór ten nadniemeński będzie, miński czy dźwiński jego czar taki ciężki pamięci jak kamień młyński ${ }^{19}$.

I rzeczywiście, gdziekolwiek los poetkę rzucił, wszędzie odzywały się sporadycznie jakieś okruchy wspomnień, jakieś skłonności wydobywania z obcego pejzażu przede wszystkim tego, co swojskie, co utkwiło w pamięci jeszcze w latach spędzanego na Litwie i Łotwie dzieciństwa. Echa podobnych wspomnień odzywają się niejednokrotnie $\mathrm{w}$ wierszach powstałych podczas wojennej tułaczki po klęsce wrześniowej, jak na przykład Listy z Norwegii:

\author{
Zaśnieżone gałęzie z dziecinnych lat, \\ garbate zaspy, śniegi; \\ jakiż tu czar na was padł, \\ że was odnajduję w Norwegii? \\ Światła błyskają z chałup,
}

18 E. Kuźma, Regionalizm, [w:] Słownik literatury polskiej XX wieku, pod red. A. Brodzkiej i in., Wrocław 1992, s. 925-930.

19 K. Iłłakowiczówna, dz. cyt., s. 210. 


\author{
świerki w trawie po pas \\ i wszędzie las... \\ Jak to się stało? ${ }^{20}$
}

W niektórych wypadkach, jak wynika z powyższego przykładu, w obcym pejzażu odnajduje jakieś swojskie elementy, w innych znowuż dominuje właśnie bezpośrednio nazwana świadomość obcości. „Nie nasz kamień i badyle nie nasze / Od obcych pagórów chude wietrzysko gwiżdże [...]" - pisała w cyklu Kur siedmiogrodzki z tomu Wiersze bezlistne (1942).

Jeszcze w innych wypadkach pojawia się swego rodzaju ambiwalencja. W Wierszach z Anglii ze zbioru Lekkomyślne serce (1959) tytułowa Anglia jest postrzegana jako „Taki sam prawie kraj...”, jednakże z pewnym zastrzeżeniem:

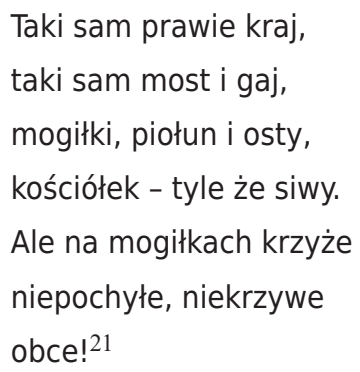

Cóż daleka Anglia, skoro w Polsce nie zawsze i nie wszędzie czuje się poetka dobrze. Chociaż elementy krajobrazowe „małej ojczyzny” pojawiają się w jej twórczości z biegiem lat coraz rzadziej, sporadycznie, chociaż sięga po motywy uniwersalne bądź związane z aktualnie towarzyszącymi realiami społeczno-politycznymi, nie można twierdzić, że czuje się z nimi głęboko związana. Nawet miasto jej stałego zamieszkania po powrocie w 1947 roku z wojennej tułaczki nie stało się miejscem stabilności i zakorzenienia. Po dziesięciu latach oswajania się czuje się poetka $W$ Poznaniu na wygnaniu.

Jakieś echa bardziej swojskiej, kresowej ojczyzny odzywają się także w tomiku Szeptem (1966), zwłaszcza w cyklu Bicze z piasku. Podmiot tych

20 Tamże, s. 255.

21 Tamże, s. 307. 
wierszy coraz wyraźniej uświadamia ulotność pamięci, nietrwałość wspomnień. Nieprzypadkowo operuje obrazami „piasku”, „osypiska”, „mil sypkich”, „wyrwy”, „piachu”, o którym się mówi:

\author{
Nie przeminął, cofnął się głębiej \\ w niepamięć... \\ Bahun i kępy żurawin \\ zamknięte na siedem pieczęci $[\ldots]^{22}$
}

Podmiot nie jest w stanie zaniechać powrotu do przeszłości i jednocześnie uświadamia, że czeka nań niewdzięczna praca „kręcić / z piasku bicze”.

Podsumowując, można stwierdzić, że zapamiętana w dzieciństwie i młodości łotewska czasoprzestrzeń Kazimiery Iłłakowiczówny z biegiem lat znacznie się odrealnia, rozpływa we mgle, roztapia. Znika precyzja opisu, charakterystyczna dla jej poetyki lat trzydziestych. Pozostają w pamięci coraz mniej liczne obrazy i rekwizyty tej przestrzeni, a więc mamy tu nieco inne podejście do wspomnień niż występujące, na przykład, w późnej poezji Czesława Miłosza, który bardzo często odwiedza krainę pamięci i przywołuje wciąż nowe, plastyczne szczegóły.

W późnej twórczości Iłłakowiczówna, w odróżnieniu od noblisty, rezygnuje z realistycznych, nadających się czasem wręcz do prozy, opisów. Jednakże w sposób bardziej zakamuflowany, symboliczny, ukrywając się pod postacią „obieżyświata”, ogłasza Powrót do tego, co ją ukształtowało. Obieżyświat, który nie mógł dobrać miejsca na spoczynek, zaakceptował dopiero taki krajobraz:
[...] Ale teraz przed nim wrzos i cząber, pagóreczki, wydmy suche, okrągłe, piasek, piasek, kędy spojrzeć - piasek... I położył się tam obieżyświat... I na wieki zasnął23.

Czyż nie jest to powrót, tym razem wieczysty, do swojskiej przestrzeni kresowego dzieciństwa?

22 Tamże, s. 325.

23 Tamże, s. 326. 


\section{Bibliografia}

Iłłakowiczówna K., Poezje, wybrała i wstępem opatrzyła M. Wełna, Lublin 1989.

Iłłakowiczówna K., Poezje wybrane, Warszawa 1995.

Iłłakowiczówna K., Trazymeński zając, Kraków 1968.

Iłłakowiczówna K., Wiersze zebrane, t. 1-2, Warszawa 1971.

Kuźma E., Regionalizm, [w:] Słownik literatury polskiej XX wieku, pod red. A. Brodzkiej i in., Wrocław 1992, s. 925-930.

Ołdakowska-Kuflowa M., Chrześcijańskie widzenie świata w poezji Kazimiery Iłłakowiczówny, Lublin 1993.

Turkiewicz H., Motywy bałtyckie w poezji Kazimiery Iłłakowiczówny, [w:] Meninis tekstas: Suvokimas. Analizè. Interpretacija, nr 6 (1), Vilnius 2008. 